\title{
Addressing the Time Lag Dilemma in Curriculum Renewal towards Engineering Education for Sustainable Development
}

\author{
Cheryl J. Desha \\ School of Engineering, Griffith University, Brisbane, and \\ The Natural Edge Project, hosted by Griffith University and Australian National University, Australia

\section{Karlson (Charlie) Hargroves} \\ Science, Environment, Engineering, and Technology Group, Griffith University, Brisbane, and \\ The Natural Edge Project, hosted by Griffith University and Australian National University, Australia.

\section{Michael H. Smith} \\ Fenner School of Environment and Society, Australian National University, and \\ The Natural Edge Project, hosted by Griffith University and Australian National University, Australia.
}

\begin{abstract}
Purpose - The authors present the case for engineering departments to undertake rapid curriculum renewal towards engineering education for sustainable development (EESD), to minimise the department's risk exposure to rapidly shifting industry requirements, government regulations and program accreditation. The paper then outlines a number of elements of rapid curriculum renewal.

Design/ Methodology/ Approach - The authors begin by proposing that Higher Education Institutions face a 'time lag dilemma', whereby the usual or 'standard' curriculum renewal (SCR) approach to embed new knowledge and skills within the curriculum may take too long, lagging behind industry, regulatory, and accreditation shifts. The authors then outline a proposed rapid curriculum renewal (RCR) approach. The authors present a number of preliminary 'elements of rapid curriculum renewal' formulated from a literature review of numerous existing but largely ad hoc examples of curriculum renewal within engineering and other discipline areas, together with the authors' experience in trialling the elements.
\end{abstract}

Findings - The authors conclude that a strategically implemented process of curriculum renewal to EESD can help a department address its risk exposure to likely and impending shifts in industry, regulations and accreditation. A number of examples of implementing 'elements of rapid curriculum renewal' are emerging and this literature can inform a strategic approach to curriculum renewal.

Practical Implications - The authors aim to highlight the potential risks and opportunities for engineering departments as they consider 'how far' and 'how fast' to proceed with curriculum renewal for EESD, along with providing an overview of a range of options for implementation.

Originality/ Value - This paper fulfils an identified information/resources need.

Keywords - Time Lag Dilemma, curriculum renewal, EESD

Paper Type - Viewpoint 


\section{Acknowledgements}

The authors are members of The Natural Edge Project (TNEP), which is a not-for-profit partnership for research, education and policy analysis on sustainable development. Formerly hosted by Engineers Australia (2002-2006), the project is now hosted by Griffith University and the Australian National University (www.naturaledgeproject.net). TNEP's mission is to contribute to and succinctly communicate leading research, case studies, tools and strategies for achieving sustainable prosperity across government, business and civil society, receiving mentoring and support from a wide range of experts and leading organisations in Australia and internationally, through a generational exchange model.

The following colleagues are thanked for their valuable time in mentoring, reviewing and providing contributions to this paper (in alphabetical order):

Professor Neil Dempster, Griffith University, Australia; Dr Didac Ferrer-Balas, Universitat Politècnica de Catalunya, Spain; Professor John Fien, Royal Melbourne Institute of Technology, Australia; Professor Don Huisingh, University of Tennessee, and Editor in Chief of the Journal of Cleaner Production; Dr James Newell, Rowan University, America; Dr Karel Mulder, Delft University of Technology, Netherlands; Professor Ned Pankhurst, Griffith University, Australia; (the late) Mr Hisham Shabiby, Vice President, World Federation of Engineering Organisations; Mr Niek Stutje, Delft University of Technology (masters student); Associate Professor Magdalena Svanström, Chalmers University of Technology; and Professor David Thiel, Griffith University, Australia.

The authors would also like to thank the following workshop participants for their general input regarding EESD challenges and opportunities: 2007 International Conference on Engineering Education and Research - Workshop on 'Elements of Curriculum Renewal to Embed Sustainability into Engineering Education' workshop (iCEER 2007, 7 December 2007, Melbourne, Australia); Australasian Association of Engineering Education Conference - Workshop on 'Emerging Engineering Education Curriculum for Sustainable Development' workshop (A2E2 2007, 12 December 2007, Melbourne, Australia); and 2008 Engineering Education for Sustainable Development Conference - Workshop on 'Accelerating Curriculum Renewal - Behaviours, Barriers and Benefits' workshop (EESD08, Graz, Austria). 


\section{INTRODUCTION}

Engineering educators around the world are witnessing a significant shift in societal expectations of the engineering profession, to help address immediate and longer-term sustainable development challenges. Over the last few years in particular, there have been unprecedented calls for society to both mitigate greenhouse gas emissions, and to adapt to an altered climate regime, the nature of which will be dependent on the extent of mitigation (Stern, 2007; IPCC, 2007; Gore, 2006). Although progress toward sustainable development since the Brundtland Commission's report has been slow (World Commission on Environment and Development, 1987), significant efforts are now visible across government, business and society. There is a renewed and growing appreciation across societies around the world of the complexity of environmental systems (Brown, 2007) and how difficult it is to align development goals with the requirements for the healthy operation of these systems (UNEP, 2007; Hargroves and Smith, 2005). Within the education sector, there has also been a global call for capacity building in the 2005-2014 Decade of Education for Sustainable Development (UN General Assembly, 2002). As sustainable development advocate and expert, Jonathan Porritt acknowledged at the 2007 Global Sustainability Forum on the future for engineering education (Imperial College, London), "The 'business as usual' model, where profits come before sustainability, is absolutely finished. We now have a window of ten to 15 years to adopt a sustainable approach before we reach a global 'tipping point'the point at which mankind loses the ability to command growth and development" (Porritt, 2007).

There is also a growing body of literature on the need for Engineering Education for Sustainable Development (EESD), including a range of reports by professional, academic and governmental agencies, ${ }^{1}$ surveys, ${ }^{2}$ declarations, ${ }^{3}$ and numerous papers by academics from around the world on initiatives to embed sustainability within engineering curriculum. ${ }^{4}$ However, a literature search on the state of EESD could not find a rigorous global or national review of the discipline, which is problematic for engineering educators in addressing what needs to be done. In the absence of such a reference point, the authors have concluded from their literature review of more than 100 publications on the topic of EESD, a definitive common and growing global concern about the lack of sustainability content in engineering curriculum. In discussing this concern, WFEO President and former President of The Institution of Engineers Australia, Barry Grear AO reflected to the authors that, 'In light of the wealth of information available to the engineering profession, there is significant impetus to review what we do and how we do it. However, our references to Sustainable Development are for the most part still at too high a level. There must be a greater degree of detail provided by educators so that students have to think very carefully about the issues at hand. It is sobering for our profession to realise that this is not yet the norm for most of our engineers in training' (Grear, 2008).

Within this context, it is logistically improbable that the engineering profession will be able to equip itself 'overnight' with the knowledge and skills needed to address the range of complex challenges facing society. Rather, capacity building is needed over time on many levels, requiring a process of curriculum renewal across undergraduate education, postgraduate (also called 'masters', or 'graduate') education, $\mathrm{PhD}$ research, and professional development for practising engineers and educators. From the EESD literature authors have distilled a number of emerging 'top down' and 'bottom up' factors that appear to be putting pressure on engineering departments (also known as schools, colleges or faculties) to undertake such capacity building, including: tightened legislation and regulations; increased accreditation requirements; shifts in industry demands for graduates with sustainable development capabilities; and shifts in the demands of the students themselves. Faced with these emerging factors, engineering educators may well be asking themselves 'how far and how fast is my institution willing and able to proceed to make the transition to EESD?'.

This paper begins by describing what the authors perceive to be a significant 'time lag dilemma' now facing engineering educators (referred to herein as 'staff'), where an engineering department's decision about the scale and pace of curriculum renewal for EESD in undergraduate curriculum may significantly affect their risk profile in a rapidly changing industry, regulatory, and accreditation environment. The 
observed dilemma is that updating engineering curriculum using 'standard' (i.e. usual) methods, and the associated timelines of between 15 - 20 years (i.e. 3-4 program accreditation cycles), may expose the engineering department to potential risks with regard to student demand for the program/s, tightening accreditation requirements and ultimately program viability.

In the past, engineering departments who considered addressing this 'time lag dilemma' and risk exposure with regard to EESD faced an additional challenge in the form of a relative lack of literature on how this transition could occur, or what risks might be involved in the transition (for example in moving ahead of the market demand). In this paper, the authors attempt to address this impediment to moving forward, proposing a number of emerging 'elements of rapid curriculum renewal' which departments could use to develop their strategic plan, drawing on existing literature, ${ }^{5}$ the authors' own experiences and that of their colleagues (see Acknowledgements). The authors acknowledge that engineering departments will differ in their approach to engineering education as a result of factors including market positioning, staff expertise, pedagogical approach, and institutional culture. In such a highly diverse teaching environment, professional affiliations such as the International Engineering Alliance have advocated 'Outcome-Based Education'" to ensure quality in engineering education, and this approach has subsequently been widely adopted internationally (International Engineering Alliance, 2007). Hence, the proposed 'elements' have been developed to fit within an outcomes-based education approach, which departments can implement at their discretion to achieve EESD.

\section{ECOLOGICAL IMPERATIVE AND THE TIME-LAG DILEMMA}

Due to the impact of past development on the environment - in particular since the Industrial Revolution, the predicament for society in the $21^{\text {st }}$ Century is a global one which has immediate implications for this generation (United Nations, 2005). Addressing these global challenges requires an integrated approach across all sectors of society. Such integrated efforts also need to be significantly accelerated within a limited timeframe, if we are to avoid ecosystem failure within our lifetime. This imperative the authors refer to as the 'ecological imperative'. If the impacts on the environment predicted by scientists are right - and there is significant evidence to suggest they are - then this ecological imperative will cause significant demand for graduates, especially engineering graduates, with the knowledge and skills to address such impacts. More than a decade ago, the United Nations Environment Programme Industry and Environment Centre (UNEP IE), World Federation of Engineering Organisations (WFEO), the World Business Council for Sustainable Development (WBCSD) and the French Ecole des Ponts (ENPC - one of the world's oldest engineering institutes) jointly hosted a conference in Paris on the topic of 'Engineering Education and Training for Sustainable Development', finding that, 'many practising engineers currently have no education in sustainable development. Sustainable development should in future be included in both undergraduate and postgraduate courses. Because the transition to sustainable development must be made in the next 20 years, major changes will be required in ongoing education and practising professionals will need retraining' (UNEP et al., 1997, p. 4). However, as discussed in the introduction, this transition has not yet occurred.

Within this context, the authors observe a serious 'time lag dilemma' now facing engineering educators whereby the usual or 'standard' timeframe to update curriculum may be too long (i.e. 3-4 program accreditation cycles, or 15-20 years) to meet changing industry, regulatory, and accreditation requirements. As the average pathway to achieve engineering graduate status is approximately 3 to 5 years, from enrolment to graduation, the extent of the 'time lag' in delivering graduates with new attributes then depends on how the institution embeds new content into existing programs, to the point where a student can begin studies in first year, and fully develop the new set of desired knowledge and skills by the time they graduate (i.e. 'graduate attributes'). The author's note that in addition to this curriculum 'time lag dilemma' there is also a period of 5-10 years for graduates (i.e. on the job graduate development) before they are able to effect change as professional engineers. For masters students this additional time period may be reduced. 
Figure 1 is a schematic illustration of this curriculum 'time lag dilemma' showing on the bottom axis a timeline of the major calls for change within the higher education system for ESD, starting approximately 20 years ago. The Figure shows 4 main options for undertaking curriculum renewal towards EESD, based on an accreditation cycle of 5 years, and anecdotal feedback from colleagues on the timeframes for university approval of substantial new content in programs. The figure demonstrates how an engineering department's decision regarding the pace and extent of curriculum renewal (understanding that 'not deciding' is in effect opting for the longest transition time), has implications for the department's exposure to future risks and benefits. Risks include, for example, falling student numbers, increasing accreditation difficulties, and poaching of key staff by other institutions that are progressing faster. Benefits include, for example, attracting the more students and better staff, staying ahead of accreditation requirements, attracting research funding, and securing key academic appointments and industry funding.

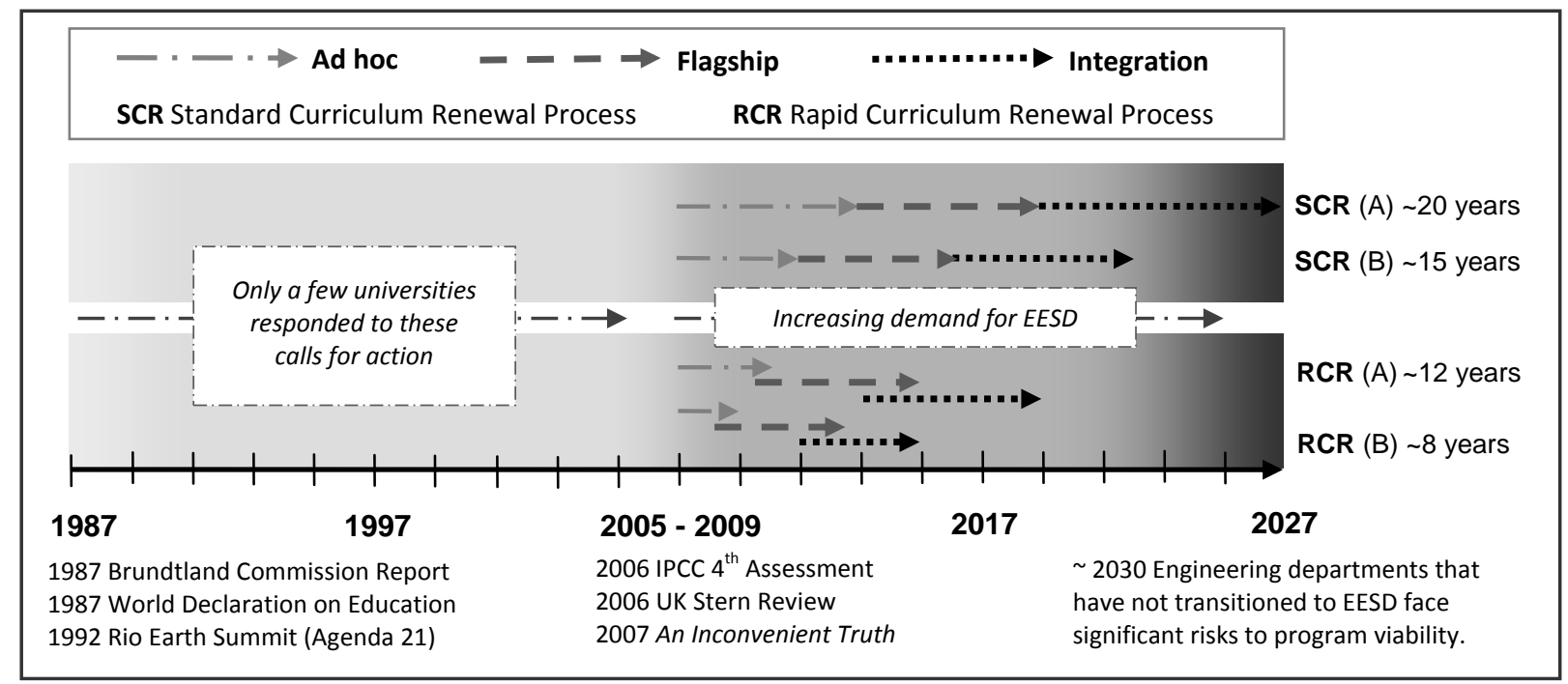

Figure 1. A schematic illustration of the time lag dilemma, showing various options for undertaking curriculum renewal towards EESD

Source: The Natural Edge Project (2008) based on an earlier version presented by Desha and Hargroves (2007)

Following the major calls for change in the late 1980s including the World Commission on Environment and Development's report Our Common Future (WCED, 1987), a relatively small number of engineering education institutions (concentrated in Europe, in particular including Delft University, Chalmers University of Technology, and UPC Spain) undertook a process of curriculum renewal to EESD in some form, primarily within undergraduate programs (Holmberg et al., 2008, and The Alliance for Global Sustainability, 2006). Following renewed calls for sustainable development between 20052009 (for example IPCC, 2006; Stern 2006; Gore 2007) and a number of subsequent market and institutional shifts around the world (for example the setting of and emissions targets and carbon trading schemes), it is likely that most departments have at least undertaken some EESD related initiatives (for example including a keynote lecture on the topic in a course). Figure 1 presents four possible future scenarios for these departments to achieve curriculum renewal, from 8 to 20 years based on differing levels of commitment (i.e. time and resources).

Each of the scenarios in Figure 1 is a combination of three core 'phases' of pedagogic activity observed by the authors. These phases are briefly outlined as follows:

1) Phase 1: Ad Hoc Exploration (Staff Initiated and Driven): In this phase, staff explore content and trial it with students. It may include a number of staff initiated and led activities, usually only involving those staff who have a particular interest in sustainability (and who may not be part of 
senior management in the department). If the department chooses not to encourage and support such endeavours as part of a longer term goal they may only continue for the time the individual staff invests in such activities, or the staff may change institutions to gain a greater level of support for the new area of exploration.

2) Phase 2: The Flagship Approach (Market Driven): In this phase, the department may bring together Phase 1 efforts through developing or renewing one or more specific courses which are targeted at one or more dimensions of sustainability, such as 'sustainable energy systems', for undergraduate, post graduate and professional development students. The department may formally establish these new 'flagship courses' to be offered in combination with existing program offerings, and may still rely on one or a few staff to run the flagship courses, while the rest of the department may continue teaching the standard curriculum (unless other staff are directly involved in the flagship courses). As new courses are successfully run and refined over a number of years, the department may gain an understanding of the market for the courses through student and industry feedback, as well as feedback from their advisory boards. Other flagship courses may subsequently be added to the curriculum.

3) Phase 3: Integration (Institution Driven): In this phase, the department may begin to integrate new content across the program offerings. Senior staff within the department may be tasked with assessing and advising how to proceed with implementing a full curriculum transition, which may result in a period of gradual integration of new content into the curriculum. Most or all staff are involved in integrating the new content into their courses. This may be for example through a management directive for sustainability to be addressed in a percentage of course outline/ overview documents (i.e. where one or more 'sustainability' tick-boxes must be considered when uploading updated course outlines to the administration centre each semester). It may also be addressed during annual staff appraisals with regard to teaching performance criteria.

The following four scenarios comprise combinations of these three phases of activity, and are broadly categorised as either 'Standard' or 'Rapid' curriculum renewal.

In a Standard Curriculum Renewal (SCR) process, the department has a low to moderate level of commitment to EESD, responding to mandatory external requirements, which might include upcoming accreditation requirements, student recruitment and retention figures, advisory board contributions, and institutional guidance (e.g. from the teaching and learning department within the university):

1. SCR-A: A department commits to continue with the current - or 'standard' pace of curriculum renewal, which might proceed over 20 years, depending on the institution's procedures. A typical transition might begin with ad hoc curriculum renewal dependent on individual staff interests, followed by a period of flagship course development, then a gradual transition to full integration of sustainability within the curriculum, but only as is forced upon the institution by external requirements.

2. SCR-B: A department may move through ad hoc, flagship and integrated curriculum development more quickly (although still in a linear manner) over a period of around 15 years, with department managers recognising and formalising EESD initiatives and subsequently planning integration, reducing the timeframe for the transition by perhaps a full cycle of accreditation.

Institutions choosing to continue along the 15-20 year SCR curriculum renewal path and wait for the rigorous proof and rationale for EESD before acting faster, face a future risk that market and institutional changes might overtake their department's curriculum renewal progress, causing their product (i.e. education) to fall behind employer demand. In short, if commitment is low then the department's exposure to future risk is high (for example with respect to falling student numbers with diminishing reputation, frustrated staff moving to institutions that are moving faster, or being poached 
by other institutions and employers) and the future potential for benefits is low (for example with respect to recruiting top educators and researchers in the field).

In contrast, in a Rapid Curriculum Renewal (RCR) process, the department has a high commitment to EESD and is in control of the pace rather than reacting to staff, market or institutional drivers. The department is positioning itself strongly for future changes to industry, regulatory and accreditation requirements:

3. RCR-A: A department invests in condensing the curriculum renewal process to around 12 years. Ad hoc curriculum renewal is still advantageous initially, as it can help to build momentum, knowledge and understanding. Flagship course development might be initiated, then continue to be developed while the department concurrently proceeds with rolling out a full integration of sustainability content as appropriate across the rest of the program.

4. RCR-B: A department invests in condensing the curriculum renewal process to around 8 years, by immediately proceeding with planning for flagship and integration of sustainability content while the staff develop and trial the new content. This forward planning facilitates swift uptake of new content in formalised flagship courses once it has been successfully trialled and concurrent integration of the content across other courses in the program.

Hence, as the level of commitment to EESD increases, future risk exposure to changing market and institutional requirements reduce and the future benefits increase. However, it is important for departments to be strategic about the transition to EESD, to ensure that their graduates remain employable and in demand throughout the transition. The question of 'how' to strategically make this transition is addressed in the following section.

\section{EMERGING ELEMENTS OF RAPID CURRICULUM RENEWAL FOR EESD}

\section{Existing Curriculum Renewal Frameworks}

While engineering education has undergone periods of refocusing on professionalism, ethics, and health and safety, the profession has not had to make a significant shift in the way it fundamentally teaches students across all disciplines since the first engineering professionals emerged following the Industrial Revolution (Jorgensen, 2007). As Haghighi et al (2008) note, 'Engineering education now enjoys a community of scholars and researchers, an emerging body of core knowledge, an identified research agenda and framework, recognized culture and vocabulary, avenues of dissemination in peer-reviewed journals ... We must leverage all such disciplinary resources to rapidly fulfil a clear mission to reform the pedagogical practice of educating engineers - a practice that has been relatively static and wed to the didactic teaching styles of the first universities established over 800 years ago'.

A review by the authors of more than 100 papers in engineering higher education literature ${ }^{[7]}$ has found that most literature documents the barriers and challenges to curriculum renewal such as those described in Holmberg and Samuelson (2006), by Wormley (2004), and in numerous papers on individual course experiences. Few papers include a sense of urgency as a driver (Barnett and Coate, 2005). From this literature review, the authors note three substantial examples of projects addressing the development of processes and frameworks to guide curriculum renewal for EESD:

- The 'CDIO Initiative' provides a framework for planning curriculum and outcome-based assessment, centred around a professional engineering approach of 'Conceiving, Designing, Implementing and Operating' (Crawley et al., 2007). Led by the Massachusetts Institute of Technology, more than 30 leading engineering schools across the US, Canada, Europe, Africa, and the Asia-Pacific region have committed to introduce a number of principles into their engineering 
curriculum using this framework, including sustainable development. However, Wedel et al (2007) have identified through implementation, although the CDIO syllabus includes the philosophy of sustainability, sustainability terminology is not made explicit (i.e under a separate headline), which would be beneficial to improve its useability for curriculum renewal to EESD. Some critics have interpreted the inclusion of sustainability components in sub-headings only as a 'downprioritization', and there is also a lack of examples describing sustainability learning experiences in CDIO-based programs.

- In the 1990s the American Accreditation Board for Engineering and Technology (ABET) undertook a 'SUCCEED' project, which provided a curriculum renewal methodology for engineering departments to systematically undertake curriculum renewal in response to changes to accreditation requirements (Speicher, 1994). Essentially the methodology involved a five-stage process, including preparation, strategic planning, analysing existing curriculum, designing new curriculum, and implementing new curriculum. In the methodology, continuous curriculum improvement is achieved through periodically revisiting the process by addressing the curriculum as a whole, and using formal techniques to improve course conduct (i.e. how a course is taught) and course content (i.e. what is taught in a course) (Leonard et al., 1998).

- In Australia, a number of universities are collaborating on an 'Engineering Meta-Attributes Project' (EMAP) funded by the Australian Learning and Teaching Council (formerly the Carrick Institute for Learning and Teaching in Higher Education), to examine a range of frameworks for mapping and reporting on the development of graduate attributes at program level (EMAP, n.d.). A universitybased example of such a framework is Swinburne University (Victoria, Australia). Although not specifically oriented towards sustainable development, the 'Swinburne Curriculum Framework Project' does define a vision of student learning for 2010, and develops and prioritises a set of key curriculum areas as the basis for reform of coursework programs, including developing social and environmental aspects alongside other skills (Swinburne University, 2007).

\section{Emerging Elements of Curriculum Renewal}

Drawing on these frameworks for curriculum renewal and the EESD literature referred to in the introduction, as well as learnings from a range of personal experiences (in collaboration with a number of university partners) on specific challenges, barriers and leverage points, the authors have identified a number of 'elements of curriculum renewal'. In particular, the authors looked for documented practices that were:

- Sensitive to the diversity of engineering disciplines, students, teaching pedagogy and cultures present in engineering departments;

- Achievable within the budget and resourcing constraints common to engineering departments in an increasingly competitive industry;

- Flexible enough to fit within existing curriculum renewal structures, as well as country and international accreditation requirements;

- Supportive of departments just beginning a rapid transition path to EESD, in addition to departments who are already on their way and seeking to improve further; and

- Practical in the organisation of considerations and tasks, but implementable in a linear or non-linear manner, depending on the culture of the department. 
The emerging 'elements of curriculum renewal' are summarised below. The refinement and exploration of these elements form the focus of the authors' research collaborations with university partners internationally and are being developed for further publication. Hence, the authors invite readers to provide direct comments to enable the material to be enhanced in the future.

Element 1: Awareness Raising and Developing a Common Understanding - This element involves bringing staff to a common understanding of 21 st Century engineering challenges and opportunities, and implications for curriculum renewal in their department. With this information, staff might then consider how this will affect their role within the department. Developing a common understanding throughout the department does not mean that everyone has to agree, or 'conformity' needs to be achieved. Rather, staff need to be aware of how EESD affects the department, and the department's perspective.

As staff reach this level of understanding, senior management in the department can also identify what capacity is available to deliver sustainability content within the program offerings, including existing champions, leaders, and interest areas among staff. This element may be under-taken 'top-down', 'bottom-up' and 'middle-out', through activities such as keynote lectures, public addresses, lunchtime seminars, media articles, and profiling of existing sustainability related initiatives and/or champions within the university community.

Element 2: Graduate Attribute Mapping - This element involves appropriately facilitated scoping workshops with academic staff and other collaborators within the university hierarchy, to focus on the university's 'Graduate Attribute' requirements for graduating students and how sustainability knowledge and skills relate to these requirements. Making a transition to engineering education for sustainable development does not mean 'starting from scratch'. Rather than replacing the content of existing courses, the curriculum renewal process is about rethinking relevance of the theory, knowledge and applications to deliver revised graduate attributes and skills. This process may be implemented through one or more scoping workshops, where key staff systematically develop a list of desired graduate attributes and investigate the potential for such attributes to be delivered across the program, via a attribute mapping exercise.

Element 3: Curriculum Audit - This element provides a strategic opportunity to systematically review the extent of sustainable development content within courses, which then assists in identifying areas of focus for the introduction and consolidation of sustainable development content across a given program. A curriculum audit provides a risk management approach to the timing and prioritisation of the curriculum renewal process, while acknowledging efforts already undertaken in curriculum renewal for sustainable development. A key component for the success of this element is the direct involvement by teaching staff to enable the process to deliver an effective enhancement of the existing offering. It is important that this element be understood as a non-confrontational, pro-active and 'outcomes-based' (rather than prescriptive) approach to curriculum review that preserves the program's diversity and innovation. Course and Program Convenors have the opportunity to reflect on the course's contribution to the Program as well as form ideas for future contribution.

Element 4: Course Development and Renewal - This element involves the selection of the curriculum development and renewal plan most suitable for the department, considering the merits of possible strategies such as 'niche programs', 'flagship courses', and institutional considerations like the availability of existing content and management support. Considerations include: Should the department develop a 'Sustainability' Degree or Program? Should the department develop one or more Sustainability 'Flagship Course/s' (i.e. Flagship Approach)? Should the department support the 'Flagship Approach' with supporting courses (i.e. 'Armada Approach')? How can the department best use existing internal knowledge and expertise, and external supporting content resources? 
Element 5: Bridging and Outreach - This element involves extending the utility of course development and renewal to improve recruitment by undertaking bridging opportunities with industry and government, across undergraduate and postgraduate education, as well as high schools and within the community. Considerations include: What opportunities exist for departments to offer EESD capacitybuilding sessions for practising engineers in industry and government, to assist with existing employment (i.e. bridging)? Could departments increase student numbers for new courses in certain technologies or innovations by permitting upper undergraduate and postgraduate student enrolment, and by offering the courses to students in other institutions, in collaboration with those institutions (who might have other complementary specialist courses to offer)? How could a department use EESD to interact with potential future students, through high-school level bridging and collaboration with schools and the local community (i.e. 'outreach')?

Element 6: Campus Integration - This element involves enhancing the course development and renewal process by linking theory about education for sustainable development curriculum, with on-campus application opportunities, in effect 'operationalizing' the curriculum. With many future leaders spending time on higher education campuses, campus conservation efforts that involve students can yield educational dividends for the future. In a professional environment where staff may not have recent industry experience, on-campus initiatives can also provide staff with practical experience in their subject matter. It can also be beneficial for students to use real projects to practice what they have learned.

\section{CONCLUDING COMMENTS}

The timeframe for engineering educators to equip professionals with new skills related to environmental management and sustainable development is converging with the timeframe for the engineering community to successfully act to avoid irreversible damage to the planet's ecosystems. Despite this, evidence from engineering education literature suggests that there is still little evidence of a shift to EESD in engineering curriculum worldwide. This situation, combined with the lack of existing engineering programs that develop these attributes, has created a 'time lag dilemma' for engineering educators to address.

Ultimately, within the next 20 years, the majority of engineering departments will make the transition to EESD as society addresses the challenges of sustainable development, such as climate change. The transition will create a new order of leaders in engineering education. While some departments may miss this opportunity and perhaps close or catch up later, others may use EESD to improve both their reputation and their business performance. In the absence of immediate and broad institutional reform within the higher education sector towards education for sustainable development, the authors hope that the emerging 'elements of curriculum renewal' presented in this paper contribute to the growing body of literature on how to undertake a rapid transition, and assist colleagues in the field to strategically plan their own department's transition. As the authors' research continues with respect to the practicalities of implementing these elements within engineering and potentially other disciplines, comments on this paper are welcome. 


\section{REFERENCE LIST}

Azapagic, A., Perdan, S. and Shallcross, D. (2005), "How much do engineering students know about sustainable development? The findings of an international survey and possible implications for the engineering curriculum", European Journal of engineering Education, Vol. 30, No. 1, March 2005, pp. $1-19$.

Barnett, R. and Coate, K. (2004), Engaging the Curriculum in Higher Education, Society for Research Into Higher Education (SRHE) and Open University Press, Buckingham, UK.

Blewitt, J. and Cullingford, C. (2004), The Sustainability Curriculum: The Challenge for Higher Education, Earthscan Press, London.

Brown, L. (2007), Plan B 3.0: Mobilising to Save Civilisation, Norton, New York, available at: www.earth-policy.org/Books/PB3/Contents.htm (accessed 12 May 2008).

Crawley, E., Malmqvist, J., Ostlund, S., and Brodeur, D. (2007), Rethinking Engineering Education:

The CDIO Approach, Springer Press, New York. Information about the process is available at: http://www.cdio.org/ (accessed 1 September 2008).

Desha, C. and Hargroves, K. (2007), "Education for Sustainable Development Curriculum Audit (E4SD Audit): a curriculum diagnostic tool for quantifying requirements to embed sustainable development into higher education - demonstrated through a focus on engineering education", World Transactions on Engineering and Technology Education, UICEE, Vol.6, No.2.

Desha, C., Hargroves, K., Smith, M., Stasinopoulos, P., Stephens, R. and Hargroves, S. (2007), State of Education for Energy Efficiency in Australian Engineering Education - Summary of Questionnaire Results, The Natural Edge Project (TNEP), Australia, available at: http://www.naturaledgeproject.net/Documents/Energy_Efficiency_Survey___Summary.doc (accessed 27 July 2008).

EESD (2004), Engineering Education for Sustainable Development: Declaration of Barcelona, International Conference Barcelona, October 27-29, 2004, available at: https://www.upc.edu/eesdobservatory/BCN\%20Declaration\%20EESD_english.pdf (accessed 12 July 2008).

EMAP (n.d.), "Engineer Meta-Attributes Project", available at: http://www.uow.edu.au/cedir/programs/emap/index.html (accessed 31 July 2008).

Galloway, P. (2008), The $21^{\text {st }}$ Century Engineer: A Proposal for Engineering Education Reform, ASCE Press, Virginia

Gore, A. (2006), An Inconvenient Truth, P. C. a. P. Productions.

Grear, B. (2008), Personal Communications with the authors, 29 August 2008.

Haghighi, K., Smith, K., Olds, B., Fortenberry, N. and Bond, S. (2008), “Guest Editorial: The Time is Now: Are we Ready for our Role?”, Journal of Engineering Education, April 2008, Vol. 97, No. 2, available at:

http://findarticles.com/p/articles/mi_qa3886/is_200804/ai_n25500051/print?tag=artBody;col1 (accessed 15 July 2008).

HEFC (2007), HEFC Strategic Review of sustainable Development in Higher Education in England, Report to the Higher Education Funding Council for England by the Policy studies Institute, PA Consulting Group and the Centre for Research in Education and the Environment.

Heywood, J. (2005), Engineering Education: Research and Development in Curriculum and Instruction, Hoboken, N.J. Wiley-Interscience

Holmberg, J., and Samuelson, B. Eds. (2006) Drivers and Barriers for Implementing Sustainable Development in Higher Education, UNESCO Education for Sustainable Development in Action Technical Paper N³, September 2006. 
Holmberg, J., Svanström, M., Peet, D., Mulder, K., Ferrer-Balas, D. and Segalàs, J. (2008), “Embedding Sustainability in Higher Education through Interaction with Lecturers: Case studies from three European Technical Universities”, European Journal of Engineering Education, Vol. 33, No. 3, pp. 271-282.

Huckle, J., and Sterling, S. (eds.) (1996) Education for Sustainability, Earthscan, London.

IIES (1992), "Arusha Declaration: Statement by the World Federation of Engineering Organisations (WFEO) Environment And Development", The UNCED Conference, available at: http://www.iies.es/FMOI-WFEO/desarrollosostenible/main/assets/ArushaDeclaration.doc (accessed 31 July 2008).

International Engineering Alliance (2007), Rules and Procedures: International Educational Accords, International Engineering Alliance, pp. 40-41, available at: http://www.washingtonaccord.org/rules-andprocedures-aug-2007.pdf (accessed 3 July 2008).

IPCC (2007), Fourth Assessment Report WG2: Climate Change 2007: Impacts, Adaptation \& Vulnerability, International Panel on Climate Change.

Jorgensen, U. (2007), "Historical Accounts of Engineering Education", in Crawley, E., Malmqvist, J., Ostlund, S., and Brodeur, D. (2007) Rethinking Engineering Education: The CDIO Approach, Springer Press, New York.

King, R. (2008), Addressing the Supply and Quality of Engineering Graduates for the New Century, The Carrick Institute for Learning and Teaching in Higher Education Ltd, Sydney.

Leonard, M., Beasley, D., Scales, K. and Elzinga, D. (1998), "Planning for Curriculum Renewal and Accreditation Under ABET Engineering Criteria 2000”, Best Paper in Proceedings of the 1998 ASEE.

Lidgren, A., Rodhe, H., and Huisingh, D. (2006) "A systemic approach to incorporate sustainability into university courses and curricula" in Journal of Cleaner Production Vol. 14 pp 797 - 809.

Conference, Seattle Washington (28 June - 1 July 1998), available via the ASEE website at: http://www.asee.org/conferences/ (accessed 1 September 2008).

Levett-Therivel (2006) Sustainability carrots and sticks: the benefits and risks of sustainable development for HEIs, Report to HEFCE, available at:

http://www.hefce.ac.uk/Pubs/RDreports/2006/rd18_06/rd18_06.pdf (accessed 3 July 2008).

Marjoram, T. (2006), International Workshop: Engineering Education for Sustainable Development, Report and Recommendations of the Workshop, Tsinghua University, Beijing, 31 October - 2 November, 2006, available at:

www.wfeo.org/documents/download/EESDTsinghuaRecommsActionNov06V3.doc (accessed 6 August 2008).

Marjoram, T. (ed.) (In Press), UNESCO Report: Engineering - Issues and Challenges for Development, Produced in conjunction with World Federation of Engineering Organisations (WFEO), International Council Academies of Engineering and Technological Sciences (CAETS), International Federation of Consulting Engineers (FIDIC).

NAE (2005), Educating the Engineer of 2020: Adapting Engineering Education to the New Century, Committee on the Engineer of 2020, Phase II, Committee on Engineering Education, National Academy of Engineering of the National Academies, Washington DC.

OECD Secretariat. (2002), Indicators to Measure Decoupling of Environmental Pressure from Economic Growth, OECD, Paris.

Porrit, J. (2007), "Keynote Speech: Global Sustainability Forum: The Future for Engineering Education", available at: http://www3.imperial.ac.uk/globalsustainability (accessed 20 August 2008).

Rompelman, O. and de Graaff, E. (2006), "The engineering of engineering education: curriculum development from a designer's point of view" European Journal of Engineering Education, Vol. 31, No. 2, pp. 215-226. 
Speicher, A.L. (1994), “ASEE Project Report: Engineering Education for a Changing World Using Partnerships to Respond to New Needs in Engineering Education", ASEE Prism Magazine, pp. 20-27.

Stern, N. (2006), The Stern Review: The Economics of Climate Change, Cambridge University Press, Cambridge.

Swinburne University (2007), "Curriculum Framework Project", available at: http://www.swinburne.edu.au/hed/framework/statement.html (accessed 30 June 2008).

The Alliance for Global Sustainability (2006), The Observatory: Status of Engineering Education for Sustainable Development in European Higher Education, 2006, EESD-Observatory, Technical University of Catalonia, Spain, available at: www.upc.edu./eesd-observatory/ (accessed 17 July 2008).

The Alliance for Global Sustainability (2008), The Observatory: Status of Engineering Education for Sustainable Development in European Higher Education, 2008, EESD-Observatory, Technical University of Catalonia, Spain.

The Alliance for Global Sustainability (2006), The Observatory: Status of Engineering Education for Sustainable Development in European Higher Education, 2006, EESD-Observatory, Technical University of Catalonia, Spain, available at: www.upc.edu./eesd-observatory/ (accessed 17 July 2008).

The Royal Academy of Engineering (2007), Educating Engineers for the $21^{\text {st }}$ Century, The Royal Academy of Engineering, London.

United Nations (2005) Millennium Ecosystem Assessment. Available at www.millenniumassessment.org/en/index.aspx. (accessed 5 January 2007).

United Nations General Assembly (2002), Proclamation of the Decade of Education of Sustainable Development (2005 - 2014), 57th Session, UN General Assembly, available at: http://www.desd.org/ (accessed 20 August 2008).

UNEP (2007) Global Environment Outlook: Environment for development (GEO-4) report. UNEP. Available At http://www.unep.org/geo/geo4/ (accessed 12 December 2007).

UNEP, WFEO, WBCSD, ENPC (1997), Engineering Education and Training for Sustainable Development, Report of the joint UNEP, WFEO, WBCSD, ENPC Conference, Paris, France, 24-26 September 1997.

UNESCO (1991), World Education Report 1991, UNESCO, Paris.

UNESCO (2004), "The Shanghai Declaration on Engineering and the Sustainable Future", World Engineers' Convention, Shanghai, 5 November 2004, available at:

http://portal.unesco.org/science/en/ev.php-

URL_ID=4146\&URL_DO=DO_PRINTPAGE\&URL_SECTION=201.html (accessed 6 August 2008). United Nations (2000) The Earth Charter, United Nations, available at: http://www.earthcharter.org/ (accessed 29 August 2008).

Walkington, J. (2002), “A Process for Curriculum Change in Engineering Education”, European Journal of Engineering Education, Vol. 27, No. 2, p. 16, New York.

Weaver, P., Jansen, L., van Grootveld, G., van Spiegel, E. and Vergragt, P. (2000), Sustainable Technology Development, Greenleaf Publishing, Sheffield, UK, Foreword.

Wedel, M.K., Malmqvist, J., Arehag, M., Svanström, M. (2007) Implementing Engineering Education for Environmental Sustainability into CDIO Programs' in Proceedings of the 4th International CDIO Conference, Hogeschool Gent, Gent, Belgium, June 16-19, 2008.

WFEO (n.d.), "Engineers and Sustainable Development - Engineering Progress", available at: http://www.iies.es/FMOI-WFEO/desarrollosostenible/main/progress.htm (accessed 12 May 2008).

World Commission on Environment and Development (1987), Our Common Future, Oxford University Press, Oxford. 
Wormley, D. (2004), “Challenges in Curriculum Renewal”, The International Journal of Engineering Education, Vol. 20, No. 3, p. 4.

${ }^{1}$ Including the 2005 American National Academy of Engineering (NAE) report on educating the engineer of 2020 (NAE, 2005), the 2006 UNESCO workshop on Engineering Education for Sustainable Development (Marjoram, 2006), a 2009 UNESCO Report: Engineering - Issues and Challenges for Development (Marjoram, In Press) the 2007 UK Royal Academy of Engineering (RAE) report on educating engineers for the 21st Century (RAE, 2007) and Higher Education funding Council for England (HEFCE) Strategic Review of Sustainable Development in Higher Education in England (HEFC, 2007), and the 2007 Australian Learning \& Teaching Council (formerly the Carrick Institute) report on addressing the supply and quality of engineering graduates for the 21st Century (King, 2008).

${ }^{2}$ Including papers on surveys undertaken by colleagues such as the 2006 and 2008 Observatory publications on European efforts towards EESD (AGS, 2006, 2008), international survey findings by Azapagic et al (2005, pp.1-19) and subsequent replica-surveys, and a national survey of energy efficiency education undertaken by the authors in Australia (Desha et al, 2007).

${ }^{3}$ Including the Arusha Declaration (IIES, 1992), WFEO Statement on Engineers and Sustainable Development (WFEO, n.d.), the Barcelona Declaration on Engineering Education for Sustainable Development (EESD, 2004), and the Shanghai Declaration on Engineering and a Sustainable Future (UNESCO, 2004).

${ }^{4}$ Papers covering these topics have been sourced from journals including the European Journal of Engineering Education (European Society for Engineering Education), the Australasian Journal of Engineering Education (Australasian Association of Engineering Education), Engineering Education: Journal of the Higher Education Academy Engineering Subject Centre (UK HEA), Global Journal of Engineering Education, the Journal of Engineering Education (American Society for Engineering Education), International Journal of Continuing Engineering Education and Life-Long Learning (UNESCO), International Journal of Engineering Education, and the International Journal of Sustainability in Higher Education. Papers on these topics also appear in conference proceedings from key international mainstream events including the biennial conference on Engineering Education for Sustainable Development, the annual Global Colloquium on Engineering Education, the annual conference by the Australasian Association of Engineering Education, and papers presented at a variety of international workshops hosted by UNESCO and other network collaborators on engineering education for sustainable development.

${ }^{5}$ Notable curriculum examples of publications discussing curriculum renewal for ESD include: Huckle and Sterling eds, (1996); Levett-Therivel (2006). Galloway (2008); Lideren, Rodhe and Huisingh (2006); Blewitt and Cullingford (2004). Notable engineering curriculum renewal literature includes: Barnett and Coate (2004); Heywood (2005); Rompelman and de Graaff (2006); and Walkington (2002).

${ }^{6}$ The International Engineering Alliance seeks verification by focusing in depth on the outcomes of programs and how they are assured, using an 'outcome standard' as the overarching requirement. 